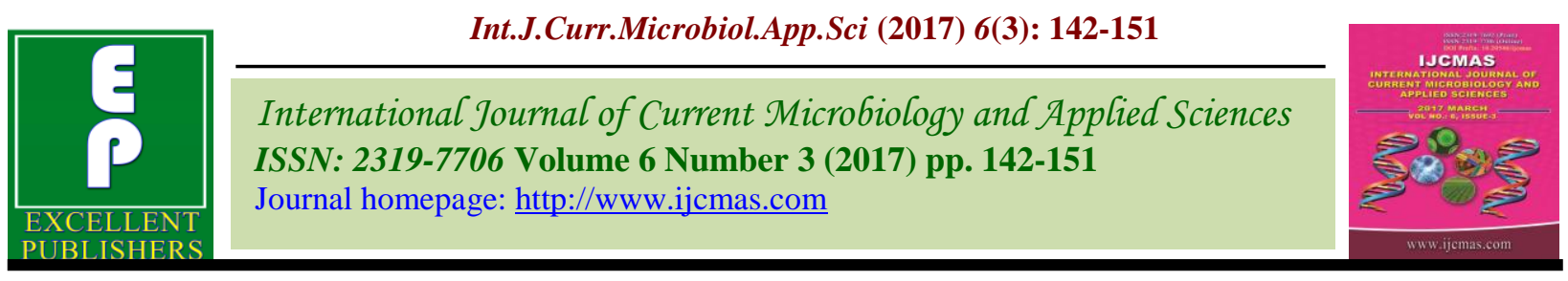

Review Article

https://doi.org/10.20546/ijcmas.2017.603.016

\title{
Precision Farming Technologies towards Enhancing Productivity and Sustainability of Rice-Wheat Cropping System
}

\author{
Sandeep Kumar ${ }^{1 *}$, Suresh Kumar Karaliya ${ }^{1}$ and Sunita Chaudhary ${ }^{2}$ \\ ${ }^{1}$ Department of Agronomy, CCS Haryana Agricultural University, \\ Hisar, Haryana-125004, India \\ ${ }^{2}$ Department of Agronomy, Banaras Hindu University, Varanasi-221005, India \\ *Corresponding author
}

\begin{tabular}{|c|c|}
\hline & A B S T R A C T \\
\hline & $\begin{array}{l}\text { The human population continues to grow steadily with the shrinking resources being used } \\
\text { for agricultural production situates great challenge against Indian agricultural system to }\end{array}$ \\
\hline Keywords & attain food and environmental security. To counter these twin challenges in the country \\
\hline Precision farming, & productivity and sustainability of the rice-wheat system for long term on scientific basis. \\
\hline $\begin{array}{l}\text { wheat cropping } \\
\text { system, } \\
\text { Sustainability. }\end{array}$ & $\begin{array}{l}\text { Precision farming (PF) looks a win-win technology towards improving the capability of } \\
\text { agricultural land to produce crops on sustainable basis. The PF is based on the concept of } \\
\text { determination of spatial and temporal variability in the crop production which in turn } \\
\text { aimed for increasing crop productivity and reducing environmental menaces. It is }\end{array}$ \\
\hline Article Info & $\begin{array}{l}\text { innovative technology which comprises the application of several Hi-tech tools like } \\
\text { Geographical Information System (GIS) Global Positioning System (GPS). Remote }\end{array}$ \\
\hline $\begin{array}{l}\text { Accepted: } \\
\text { 08 February } 2017 \\
\text { Available Online: } \\
10 \text { March } 2017\end{array}$ & $\begin{array}{l}\text { Sensing (RS), Variable Rate Technology (VRT), Decision Support System (DSS), and } \\
\text { Farmer. Precision land leveling, precision planting, precision nutrient management by } \\
\text { using Green Seeker, leaf color chart (LCC), site specific nutrient management has a lot of } \\
\text { potential for enhancing crop yield and input use efficiency under field conditions while }\end{array}$ \\
\hline & $\begin{array}{l}\text { reducing the cost of production and deleterious impacts on environmental. In India, there } \\
\text { are wide possibilities to practice a part of PF technologies in rice-wheat system. }\end{array}$ \\
\hline
\end{tabular}

\section{Introduction}

The traditional practice for application of production inputs is uniform blanket recommendation across the fields. Several studies have documented that soil properties vary across farm fields, causing spatial variability in crop yields and uniform application of production inputs is not necessarily the most efficient practice (Gaston et al., 2001). Input management using traditional practices wherein application of agricultural inputs for farming are being made irrespective of the resource characteristics have led to low input use efficiency, high cost of production and degradation of natural resources. Precision farming emphasizes the site-specific crop management practices considering the spatial variability of land in order to maximize crop production and minimize environmental damage. Precision farming or site-specific management is an "art and science of utilizing advanced technologies for enhancing crop yield while 
minimizing environmental threat to the planet", that aimed at managing soil spatial variability by applying inputs in accordance with site-specific requirements of a specific soil and crop. For enhancing the efficiency of farm inputs, increasing productivity and economics of crop production and reducing potential environmental pollution one should ensure to apply farm inputs (i) only when needed, (ii) in specific amounts inputs needed and, (iii) in specific locations of the field which can be ensured through the integration of farmers. Such management practices require quantification of soil spatial variability across the field. Precision farming is not just the use of high-tech equipments, but the acquisition and wise use information obtained from that technology. Today the precision farming technologies viz. yield monitoring, variable rate input application, precision land leveling, management zone approach, crop input determinations are being studied and adopted in various developed countries of the world. Recently in India, several techniques are being evaluated for precision input management (Sharma et al., 2005). This write-up describes the precision input management technologies (laser land leveling, precision planting, precision nitrogen management using LCC, SPAD, Green Seeker optical sensor, site-specific nutrient management, precision water management etc.) developed and evaluated that have potential role in improving crop productivity and input use efficiency in ricewheat cropping systems in Indian context.

\section{Why we need to go for precision farming}

(i) To increase production efficiency

(ii) To improve product quality

(iii) Use of chemicals more efficiently

(iv) Energy conservation

(v) To increase input use efficiency

(vi) Soil and ground water protection

(vii) Improve soil structure

\section{Components of precision farming}

Geographical information system (GIS), Global positioning system (GPS), Remote sensing (RS) and the farmer are the major components of precision farming.

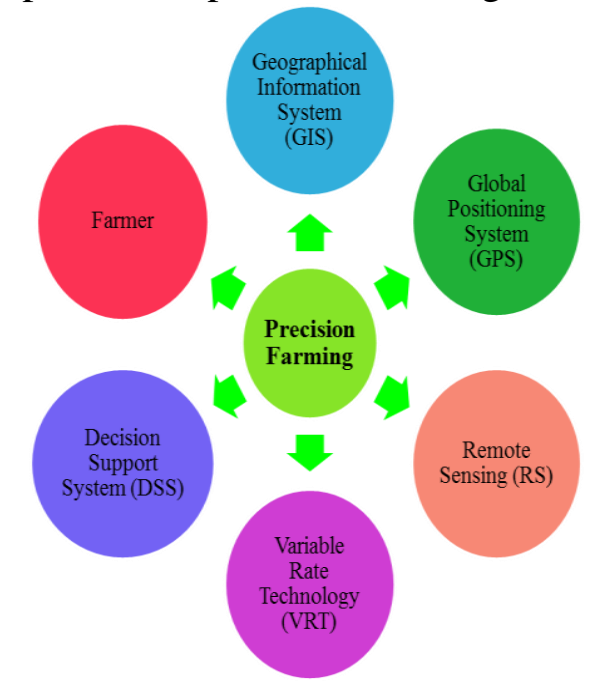

\section{Geographical information system (GIS)}

The precision farming is information based technology that concerned with spatial and temporal variability wherein GIS is the key to extracting value from information on variability. GIS is the brain of precision farming system and spatial analysis capabilities of GIS that enable precision farming.

\section{Global positioning system (GPS)}

All phases of precision agriculture require positioning information and it can be provided by the GPS (developed by the US military) in an efficient manner. The GPS provides the accurate positional information, which is useful in locating the spatial variability with accuracy. The GPS can be used in two modes; single receiver mode and differential mode (DGPS) using two receivers. Single receiver collects the timing information and processes it into position. In the differential mode (DGPS), one receiver is 
mounted in a stationary position; usually at farm office while the other is on the machine/implement.

\section{Remote sensing}

Remote sensing has been used in soil mapping, terrain analysis, crop stress, yield mapping and estimation of soil organic matter, but on a scale larger than what is required for precision agriculture. Remote sensing at high resolution can be of great use in precision farming because of its capacity to monitor the spatial variability. The remote sensing satellites send a known signal towards the earth and portion of the signal is reflected back. The image data are actively collected by measuring these signals. Data are also collected passively by measuring the sun's energy reflected by an object or electromagnetic energy emanated from an object. Remote sensing can be of various resolution, spectral coverage and frequency. In precision farming different applications will require different spatial resolutions, spectral coverage and frequencies. For eg., measurement of the intensity of disease infestation will require higher resolutions than what required for crop growth monitoring or yield mapping.

\section{Farmer}

As farming cannot be imagined without farmer, the latter must be considered as an essential component of precision farming too. For assessing and managing the variability, decision-making is the key factor, and it is to be done in consultation with the farmer. In a wider perspective, it can be visualized that farmers do practice precision farming to some extent as they make variable rate application of inputs in their different piece of fields. But, the decision is based on variability what they perceive rather than the real variability that exists. Precision farming is information and knowledge based farming. Therefore, farmers have to be trained for practicing precision agriculture, and convinced to accept the same. Further, the resource endowment and socioeconomic condition of the farmer have to be taken into consideration before prescribing any tool or step of precision farming.

\section{Approaches for precision farming}

In precision farming, inputs are to be applied precisely in accordance with the existing variability. Therefore, assessing the in-field variability soil and crop is very crucial and first step of precision agriculture. Spatial variability of all the determinants of crop yield (topography, soil properties etc) should be well recognized, adequately quantified and properly located. Construction of condition maps on the basis of the variability is a critical component of precision farming. Condition maps can be generated through (i) Surveys, (ii) Point sampling and interpolation, (iii) Remote sensing (high resolution) and (iv) Modeling.

Grid sampling was the very first approach used to develop precision application maps wherein fields are sampled along a regular grid at sample spacing ranging from $60-150 \mathrm{~m}$ depending on the field size and the samples are analyzed for desired properties. The results of these analyses are interpolated to un-sampled locations by geo-statistical techniques viz. Kriging and Inverse Distance Weighing (IDW) and the interpolated values are classified using GIS techniques into limited number of management zones. The delineation of management zones uses three GIS data layers viz. bare soil imagery, topography and farmer's experience.

One of the recent approaches to quantify soil spatial variability for site-specific management is to divide fields into productivity level management zones. A 
management zone is a sub-region of a field with homogeneous yield limiting factors, for which a single rate of a specific crop input is appropriate. A field can be divided into three different zones: high, medium and low based on the productivity of the area and the crop inputs can be applied accordingly.

\section{Precision land leveling for managing landscape variability}

Unevenness of the soil surface influences the farming operations, energy use, aeration, crop stand and yield mainly through nutrient-water interactions. Land leveling is a precursor to good agronomic, soil and crop management practices and the levelness of the land surface has significant influence on all the farming operations. Precision land leveling is one of the few mechanical inputs in intensively cultivated irrigated farming that meets the twin objectives of achieving a better crop stand, first, saving of irrigation water and second, improving the input use efficiencies. The development of laser technology for precision land leveling has been rated as second only to breeding of high yielding varieties. Precision land leveling is the process of smoothening of land surface \pm 2 $\mathrm{cm}$ from its average elevation. In spite of the known benefits of precision land leveling, Indian farmers are unable to take full advantage of it and have to rely on traditional methods of land leveling which are laborintensive and crude and do not achieve a high level of smoothness of land surface. Laser assisted precision land leveling technique is well known for achieving higher level of accuracy in land leveling. The laser leveling technology offers a great potential for water saving (20-35\%), improve crop establishment and thereby increase crop yields (10-20\%), and better environmental quality. It is estimated that extension of laser-assisted precision land leveling system to just two million hectare of area under rice-wheat system could save 1.5 million hectare-meter of irrigation water and save diesel up to 200 million liters (equal to US $\$ 1400$ million), and improve crop yields amounting to US\$ 500 million in three years and reduce GHG emissions equivalent to 500 million $\mathrm{kg}$ (Jat et al., 2006). Laser-assisted precision land leveling system is also likely to increase the cultivable area in the range of 3-6 percent (due to reduction in bunds and channels in the field). Significant improvement in water productivity and higher crop yields were reported due to laser land leveling compared to conventional practice. The water productivity (WP) of rice with same land configuration and fertility level was improved from 0.55 in traditional leveling to $0.91 \mathrm{~kg}$ grain $\mathrm{m}^{-3}$ water in precision land leveling. Similarly it was improved from 0.82 to 1.31 in wheat.

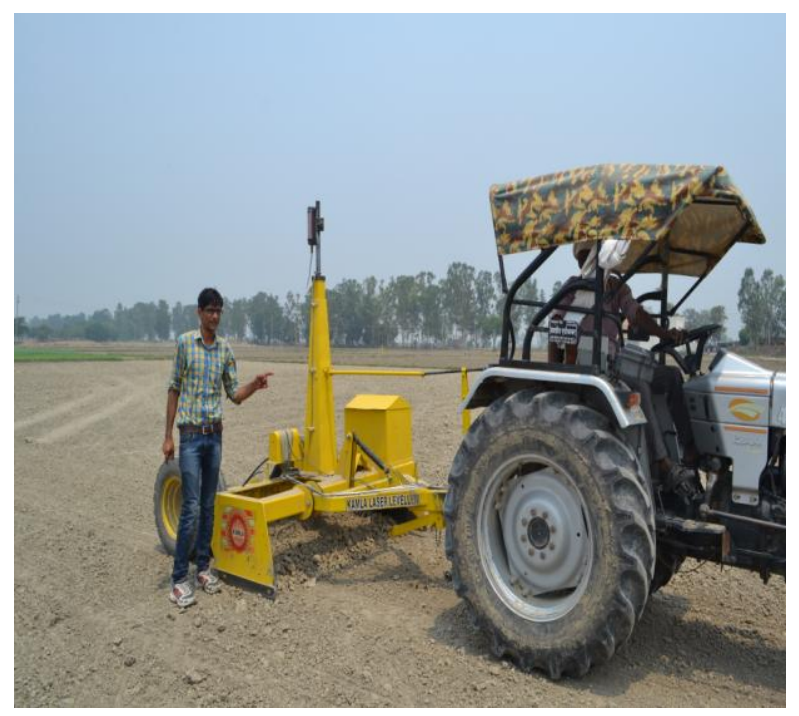

The results of sixteen participatory research trials on effect of laser leveling on crop yield and water productivity of direct seeded rice (DSR) and puddled transplanted rice (TPR) in western Uttar Pradesh under USAID funded PDCSR-RWC collaborative project revealed that the rice yield both under DSR and TPR increased with laser land leveling compared to traditional land leveling. The interactive effects of rice crop establishment and land leveling revealed that the average yield of rice 
with laser land leveling (5.33 $\mathrm{t} \mathrm{ha}^{-1}$ ) was $5.75 \%$ higher compared to traditional land leveling (5.04 $\mathrm{t} \mathrm{ha}^{-1}$ ) practices. Further, it was recorded that the water saving due to laser leveling compared to traditional leveling was more in TPR (1338 $\left.\mathrm{m}^{3} \mathrm{ha}^{-1}\right)$ than the DSR $\left(1271 \mathrm{~m}^{3} \mathrm{ha}^{-1}\right)$. This technology has shown tremendous potential for improving crop yields and water productivity mainly in irrigated farming.

Furthermore, on laser leveled fields, the performance of different crop establishment options such as of zero tillage, raised bed planting, and surface seeding are known to improve significantly. Significant increase in agronomic efficiency (AE) of applied $\mathrm{N}(A E$ $N$ at $120 \mathrm{~kg} \mathrm{ha}^{-1}$ ) under precision leveling and raised bed planting (PLRB) technique compared to traditional leveling and flat bed planting systems on a sandy loam soil at Modipuram has been reported (Jat et al., 2007) during two consecutive years. They further reported that the efficiency of the nutrient under precision leveling flat beds (PLFB), and traditional leveling raised beds (TLRB) was statistically at par but significantly superior to traditional leveling flat beds (TLFB).

\section{Paybacks of laser land leveling}

The benefits of laser land leveling over other land leveling methods include the following:

- Precise level and smoother soil surface

- Reduction in time and water required to irrigate the field

- Uniform distribution of water in the field

- Uniform moisture environment for crops

- Good germination and growth of crops

- Less seed rate, fertilizer, chemicals and fuel requirements

- Improved field traffic ability (for subsequent operations)

\section{Precision planting}

Seed is becoming a costly input and its placement at desired place and in required amount needs special attention. Manual sowing / planting is still a common practice in India, which has to do away with low cost precision planters provided with précised seed metering devices to ensure optimum plant population at lesser seed rates. Design and development of new generation multi-crop planters with precise seed metering systems are a step forward in the precision planting. A handful of reports on effect of these technologies revealed that the water productivity of the R-W system improved significantly though saving on irrigation water and/or improvement in crop yields. The research trial conducted in Pabnana command area of Haryana revealed that both irrigation and gross water productivity of wheat was remarkably improved under zero tillage compared to conventional tillage at all levels from plot to water course level (Chandra et al., 2007). Several reports and findings of researcher and farmer managed trials revealed better crop establishment and higher crop yields with less seed rates using these precision planters particularly in high value crops.

\section{Precision nutrient management}

\section{Site-specific nutrient management}

In India, fertilizers are generally broadcasted on the basis of so-called recommended doses. As these recommendations are made for either national or state basis, they are always erroneous for a particular field. Site-specific nutrient management (SSNM), a general concept for optimizing the supply and demand of nutrients according to their variation in time and space, is being tried in India for achieving the high yield targets. The within-field variability in relatively large 
fields can be managed using geo-referenced variable rate technology of nutrient management i.e. SSNM. A single field of usually $0.2-1.0$ ha size is probably the smallest feasible management unit because managing within-field variation is difficult without geo-referencing. Hence, smaller field units in India offer opportunity for sitespecific nutrient management. Not only the location of nutrient placement, but also the amounts and the depth of placement has greater role in improving efficiency of applied fertilizer nutrients. In this direction, the low cost precision instruments or fertilizer drills must substitute the manual broadcasting which is aggravating the already existing variability. The SSNM practice responds significantly not only to the primary nutrients but also to the secondary and micronutrients due to emerging deficiencies for the targeted yields. In an investigation on SSNM in hybrid rice-wheat cropping system at Modipuram (Shukla et al., 2004), the SSNM package $\left(\mathrm{N}_{170}, \mathrm{P}_{30}, \mathrm{~K}_{120}, \mathrm{~S}_{20}, \mathrm{Zn}_{7}, \mathrm{Mn}_{17}, \mathrm{~B}_{0.6}\right.$ in rice and $\mathrm{N}_{150}, \mathrm{P}_{30}, \mathrm{~K}_{120}$ in wheat) resulted in significant yield advantages both in rice $(9.95$ $\mathrm{t} \mathrm{ha}^{-1}$ ) and wheat (5.94 $\left.\mathrm{tha}^{-1}\right)$ compared to soil test lab response (STLR), local ad-hoc recommendation (LAR) and farmers' practice (FP). They further reported that the increase in net income (US\$ ha ${ }^{-1}$ ) in SSNM was 471, 384 and 377 respectively over FP, STLR and LAR. The higher crop yields with SSNM at same water use as recommended and farmers' practice ultimately leads to higher water productivity.

\section{Real time nitrogen management using leaf color chart (LCC) and SPAD meter}

Diagnostic surveys on nutrient management practices prevailing in rice in Indo-Gangetic Plain Region of India revealed that nearly one-third of rice farmers apply as much as $180 \mathrm{~kg}$ fertilizer $\mathrm{N} \mathrm{ha}^{-1}$ which is much higher than the recommended levels. Irrational $\mathrm{N}$ applications not only lead to less $\mathrm{N}$ recovery efficiency $(<50 \%)$, crop losses due to lodging, higher cost of production but also to nitrate leaching and pollution in ground water. The simple, handy and user friendly tools like leaf color charts (LCC) have been evaluated and are being used for real time $\mathrm{N}$ application. For real time $\mathrm{N}$ application in rice-wheat cropping system, The LCC and SPAD (chlorophyll meter) were calibrated and it was observed that there was a strong correlation $(r=0.84$ to 0.91$)$ in different genotypes of rice and wheat. The regression analysis showed a significant relationship between LCC and SPAD value at all growth stages for all cultivars of rice and wheat. They further reported an increase of 19 to $31 \%$ in net returns with LCC based $\mathrm{N}$ application than the fixed time $\mathrm{N}$ application. The LCC can serve as the farmer friendly tool for precision $\mathrm{N}$ management. Results of farmer participatory field trials in western UP on $\mathrm{N}$ management in Basmati rice (PB-1) revealed that rice grain yield and agronomic efficiency of $\mathrm{N}$ responded significantly positive to LCC based N application (Jat and Sharma, 2005). The highest rice yield was obtained under fertilizer $\mathrm{N}$ management using $\mathrm{LCC} \leq 3$, which out yielded to farmer, $\mathrm{N}$ management practice (100 kg N ha ${ }^{-1}$ in 3 splits) by $12 \%$. As compared to LCC $\leq 3$ the additional application of $24 \mathrm{~kg} \mathrm{~N}^{-1} \mathrm{a}^{-1}$ in $80 \% \mathrm{~N}$ as basal + LCC $\leq 3$ treated plot also did not resulted in higher grain yield, hence agronomic efficiency got decreased by $15.5 \%$. Lower yield under farmer's managed plot/ $80 \%$ basal $\mathrm{N}+\mathrm{LCC} \leq 3$ treatment even after application of 20 to $24 \mathrm{~kg} \mathrm{ha}^{-1}$ extra $\mathrm{N}$ was due to crop lodging associated with unfavorable weather conditions. By using the criteria of LCC $\leq 3$ with $20 \mathrm{~kg} \mathrm{~N}^{-1}$ per application has resulted in a total of $80 \mathrm{~kg} \mathrm{~N}$ $\mathrm{ha}^{-1}$. Although, this amount was equivalent to fixed time recommended $\mathrm{N}$ splits, it produced higher grain yield and agronomic efficiency. The increase in grain yield and agronomic 
efficiency were 8.3 and $28.8 \%$, respectively. The increase in grain yield in LCC $\leq 3$ treatment was attributed to increase in panicle number (6-8 \%), number of fertile grains/panicle (4-7 \%), grain weight per panicle (7-9 \%), and significant reduction in non-fertile grains as compared to fixed $\mathrm{N}$ splits. Results from this study indicates that agronomic efficiency of $\mathrm{N}$ in rice can be enhanced through using real time $\mathrm{N}$ management and leaf color chart (LCC $\leq 3$ for Basmati rice) may be used not only for economized $\mathrm{N}$ application but also for higher yield and profitability.
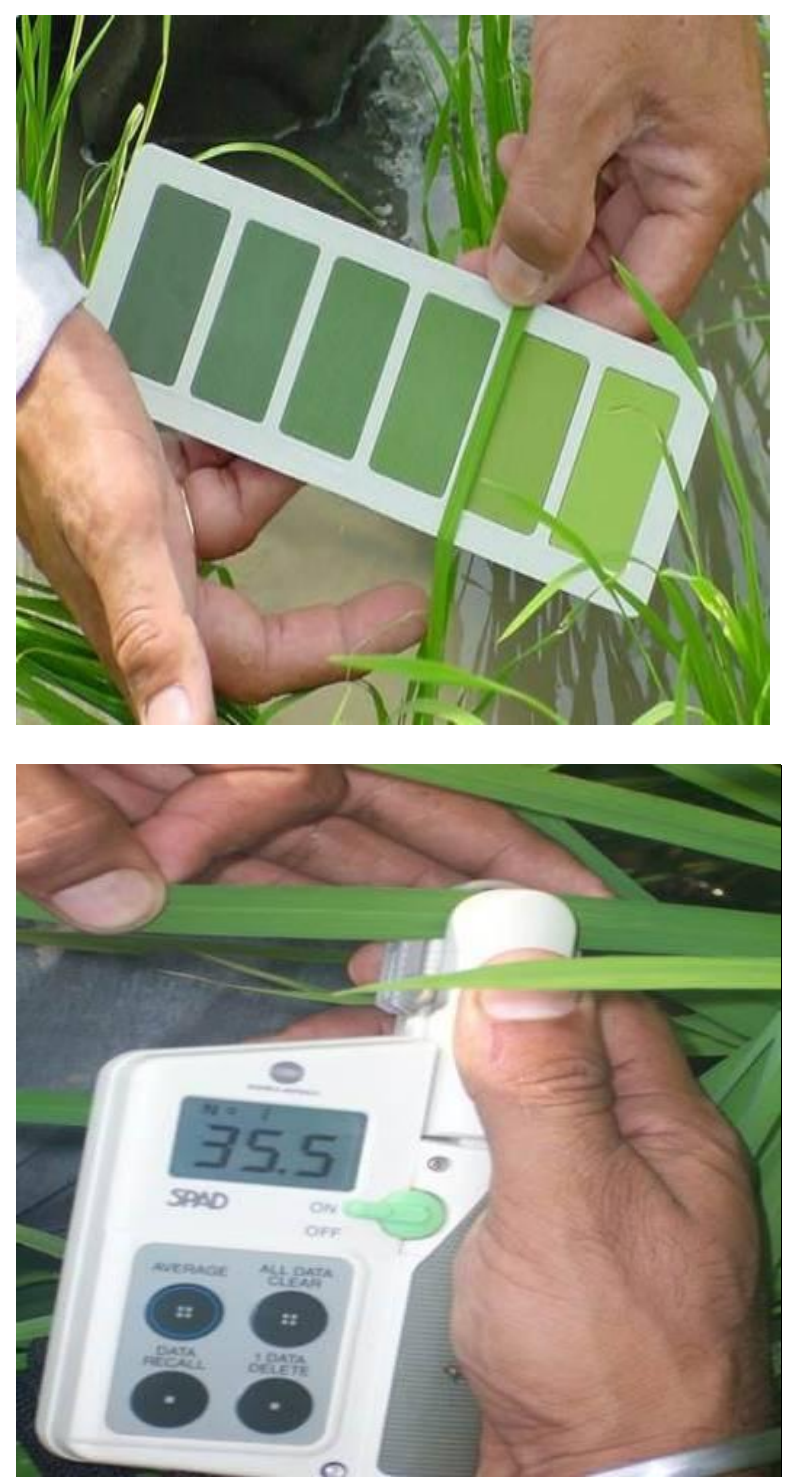

Precision nitrogen management using optical sensors (Green Seeker)

Because of the spatially variable nature of the plant available nitrogen in agro-ecosystems, crop growth and fertilizer $\mathrm{N}$ requirement vary temporally among and within seasons and spatially among and within fields. Uniform application of nitrogen fertilizer can lead to some areas of a given field receiving excessive nitrogen fertilizer while other areas are left under fertilized. Fertilizer N management that does not accommodate temporal and spatial variability may lead to suboptimal yields and net returns, poor $\mathrm{N}$ use efficiency and escape to the environment of excess fertilizer nitrogen. Thus, quantifying the optimum in-season $\mathrm{N}$ requirement is an important step towards economically and environmentally viable crop production systems. Application of nitrogen fertilizer in a spatially variable manner that corresponds to the spatial variability of the nitrogen needs of the crop could lead to increased nitrogen use efficiency and thus more economically and environmentally sound farming practices. In rice-wheat rotation, farmers generally use blanket application of higher amount of fertilizer nitrogen irrespective of the soil supplying capacity and crop demand that leads to losses of $\mathrm{N}$ as $\mathrm{NO}_{3}{ }^{-}$leaching and $\mathrm{NH}_{4}{ }^{+}$volatilization, higher cost of production and lower fertilizer $\mathrm{N}$ use efficiency. Assessing in-field variability of plant $\mathrm{N}$ status by collecting in-season biomass samples is cost prohibitive, labor intensive and destructive to the crop. Remote sensing is more rapid means to sample multiple crop parameters including photosynthetic capacity, productivity and potential yield. Spectral vegetation indices such as the normalized difference vegetation index (NDVI) have been shown to be useful for indirectly obtaining crop information such as photosynthetic efficiency, productivity potential and potential yield. NDVI is a 
broadband index that is well correlated to leaf area index and green biomass and is thus sensitive to photosynthetic efficiency.

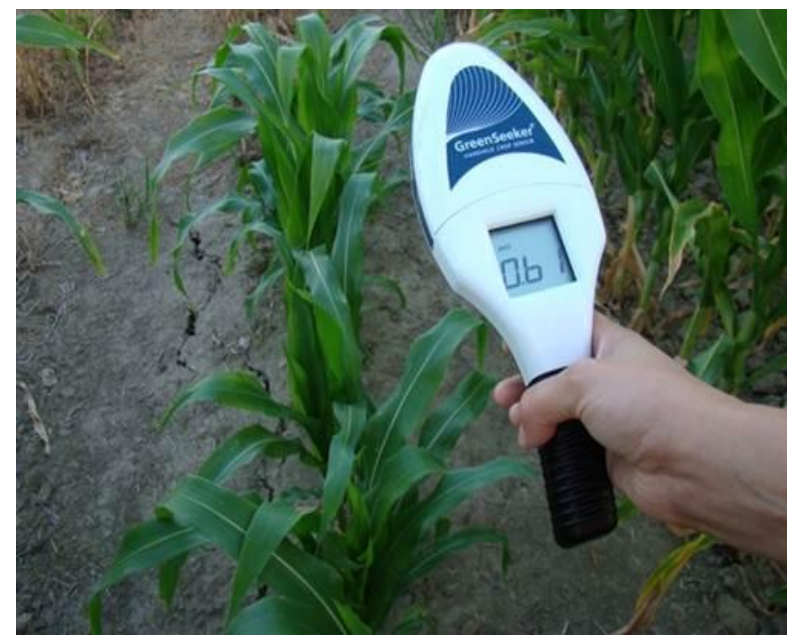

Green Seeker hand held optical sensor is onthe go remote sensing and measures the reflectance of a given crop area over a $0.61 \mathrm{x}$ $0.61 \mathrm{~m}$ area when the unit is positioned between 0.6 and $1.0 \mathrm{~m}$ above the target area (Singh et al.., 2006). The dimensions of the sensed area remain somewhat consistent over this height range. The sensor utilizes high intensity light emitted diodes (LED) to emit light in the red $(650 \pm 10 \mathrm{~nm}$ full width half magnitude) and near infra red $(770 \pm 15 \mathrm{~nm})$ bands. It records the magnitude of the reflected incident light using a photodiode detector. Green Seeker sensor embedded software calculates the reflectance in the red or green and near infrared, and then computes the NDVI. To predict grain yield and make a nitrogen fertilizer recommendation with the Green Seeker a response index (RI) is utilized. The RI is used to compare the NDVI value of a given area of interest to the NDVI value of an "N rich strip" which has received adequate $\mathrm{N}$ fertilizer for crop growth and development.

By using the NDVI data collected by the Green Seeker, the next step in determining a site-specific $\mathrm{N}$ requirement is to estimate the yield potential of the particular area without additional $\mathrm{N}$ fertilizer (other factors remaining constant). In-season estimated yield (INSEY) to correct for in-season $\mathrm{N}$ deficiency is obtained by dividing the NDVI data by the number of days from planting to remote sensing and it is essentially a measure of the daily accumulated biomass from the time of planting to the day of sensing. The yield potential with no additional fertilization $\left(\mathrm{YP}_{0}\right)$ is calculated using an empirically derived function relating INSEY to yield potential. Predicting the yield of an area of interest with additional fertilizer $\left(\mathrm{YP}_{\mathrm{n}}\right)$ is accomplished using the product of $\mathrm{YP}_{0}$ and $\mathrm{RI}$.

As per nitrogen fertilizer optimization algorithm for using Green Seeker optical sensor, relationships of in-season estimate of yield (INSEY) of rice or wheat were developed for different stages of crops using data from field experiments conducted during 2004-2006 with different crop cultivars at Ludhiana, Karnal and Modipuram in northwestern India. When INSEY-GY relationships were fitted to equation of the type $\mathrm{GY}=\mathrm{a}^{*}(\mathrm{INSEY})^{\mathrm{b}}, \mathrm{R}^{2}$ values were 0.74 and 0.77 at Feekes 5/6 and Feekes 7/8 stages of wheat, respectively. Green Seeker guided nitrogen fertilizer application in rice-wheat system resulted in remarkable increase in crop yield and fertilizer $\mathrm{N}$ use efficiency at Ludhiana, Karnal and Modipuram. They further reported that INSEY-GY relations allowed prediction of yield potential that can be achieved without fertilizer $\mathrm{N}$ application. Difference in $\mathrm{N}$ uptake between predicted yields with and without $\mathrm{N}$ fertilizer application allows calculating the quantity of fertilizer $\mathrm{N}$ that should be applied. Yields of wheat similar to that obtained by applying a blanket fertilizer $\mathrm{N}$ recommendation were obtained by applying $10-20 \%$ less total fertilizer $\mathrm{N}$ when $\mathrm{N}$ applications at Feekes 7/8 stage of wheat were guided by Green Seeker. They found that these studies suggest that 
Green Seeker can be an important tool for rational management of fertilizer $\mathrm{N}$ in the rice-wheat system of the Indo-Gangetic plain. The normalized difference vegetation index (NDVI) measured at grid scale at 70 DAS stage in wheat using spectroradiometer and Green Seeker optical sensors showed promising relationship i.e. $\mathrm{Y}=0.8028 \mathrm{x}+$ $0.1722\left(\mathrm{R}^{2}=0.84\right)$. This suggests that both the sensors can be used for measuring inseason N stress. Further, a robust relationship between NDVI measurements with green seeker and spectroradiometer and wheat grain yield supports this finding. The relationship between different aspects was as under:

Radiometer NDVI and wheat yield $(\mathrm{Y})=$ $6.0421 \mathrm{x}-1.2879\left(\mathrm{R}^{2}=0.75\right)$

Green Seeker NDVI and wheat yield $(\mathrm{Y})=$ $6.7073 x-1.8557\left(R^{2}=0.71\right)$

\section{Constraints in adoption of precision farming}

- High cost technology

- Small land holdings

- Heterogeneity of cropping systems

- Technological gaps

- Lack of local technical expertise and knowledge

\section{Misconceptions about precision farming}

- $\quad \mathrm{PF}$ is sometimes misinterpreted as sustainable agriculture

- $\quad \mathrm{PF}$ is often confused with yield mapping

- Machinery guidance and auto steer systems are tools that help with SSCM. By themselves they are not PF

In conclusion, precision farming technologies are being researched and implemented under various crops and cropping systems. Ricewheat cropping system is most suitable for adoption of this concept for higher productivity and profitability. It is evident that, the precision farming technologies are successful in their role of enhancing crop production, input use efficiency while minimizing the cost of production and environmental impacts. Precision land leveling, precision planting, real time $\mathrm{N}$ application using LCC, SSNM, have demonstrated potentialities for improving crop yields, water productivity and nutrient use efficiency and the other technologies like use of sensors, remote sensing etc are being evaluated for their potential use under real farming situation.

\section{References}

Chandra, R., Sikka, A., Singh, S., Gupta, R., Upadhyaya, A.K. and Sakthivadivel, R. 2007. Impact of resource conserving technologies on water use and water productivity in Pabnana minor of Bhakra canal system. RWC Technical Bulletin No. 10. RWC, NASC Complex, Pusa, New Delhi, pp 24.

Fraisse, C.W., Sudduth, K.A., Kitchen, N.R. and Fridgen, J.J. 1999. ASAE Paper No. 993043. International Meeting, Toronto, Ontario, Canada, July 18-21.

Gaston, L.A., Locke, M.A., Zablotowicz, R.M. and Reddy, K.N. 2001. Soil Sci. Soc. Am. J., 65: 449-459.

Hill, J.E., Bayer, D.E., Bocchi, S. and Clampett, W.S. 1991. Direct seeded rice in the temperate climates of Australia, Italy and the US. In: Direct seeded flooded rice in the tropics. IRRI, Manila, Philippines, P. 91-102.

Jat, M.L., Chandana, P., Gupta, R.K., Sharma, S.K. and Gill, M.A. 2006. Laser Land Leveling-A precursor technology for resource conservation, Technical Bulletin, RWC/CIMMYT, NASC, New Delhi p.36.

Jat, M.L., Pal, S.S. and Khosla, R. 2007. Agronomy J., (Communicated). 
Jat, M.L. and Sharma, S.K. 2005. Leaf colour chart based nitrogen management in rice. In: PDCSR Annual Report 200405, Project Directorate for Cropping Systems Research, Modipuram, India.

Jat, M.L. 2006. On-farm development and evaluation of site-specific management zone techniques for precision input application in rice-wheat system of Indo-Gangetic plains. AP Cess funded project Annual Report (2005-06). Project Directorate for Cropping Systems Research, Modipuram, India.

Khosla, R., Fleming, K., Delgado, J.A., Shaver, T. and Westfall, D.G. 2002. Use of site-specific management zones to improve nitrogen management for precision agriculture. J. Soil Water Conserv., 57: 513-518.

Khosla, R. and Alley, M.M. 1999. Soil specific nitrogen management on mild Atlantic coastal plain soils. Better Crops Plant Food, 83(3): 6-7.

Mulla, D.J. and Bhatti, A.U. 1997. In: Stafford, J.V. (ed.), Precision Agriculture, 97, First European Conference Proceedings on Agriculture, 7-10 September, Warwick University, Warwick, PP. 145-53.

Mzuku, M., Khosla, R., Reich, R., Inman, D., Smith, F. and MacDonald, L. 2005.
Spatial Variability of Measured Soil Properties across Site-Specific Management Zones. Soil Sci. Soc. Am. J., 69: 1572-1579.

Sharma, S.K., Jat, M.L. and Biswas, C. 2005. Components of precision farming. Indian J. Fertilizers, 1: 13-26.

Shukla, A.K., Ladha, J.K., Singh, V.K., Dwivedi, B.S., Sharma, S.K., Balasubramanian, V., Gupta, R.K., Singh, Y., Pathak, H., Pandey, P.S., Padre, A.T. and Yadav, R.L. 2004 Calibrating the leaf color chart for nitrogen management in different genotypes of rice and wheat in a systems perspective. Agron. J., 96: 1606-1621.

Shukla, A.K., Singh, V.K., Dwivedi, B.S., Sharma, S.K., Tiwari, K.N. 2004. Sitespecific nutrient management for maximum economic yield of the ricewheat cropping system. Better Crops, 88(4): 18-21.

Singh, B., Sharma, R.K., Jat, M.L., Singh, Y., Gathala, M., Chandna, P., Choudhary, O.P., Tripathi, S.C., Gupta, R.K., Kaur, J., Srivastava, A., Singh, I. and Gupta, R. 2006. In: Proceedings of $2^{\text {nd }}$ International Rice Congress, October 913, 2006, New Delhi, India, Pp. 388389.

\section{How to cite this article:}

Sandeep Kumar, Suresh Kumar Karaliya and Sunita Chaudhary. 2017. Precision Farming Technologies towards Enhancing Productivity and Sustainability of Rice-Wheat Cropping System. Int.J.Curr.Microbiol.App.Sci. 6(3): 142-151. doi: https://doi.org/10.20546/ijcmas.2017.603.016 